\title{
Simultaneous nitrification and denitrification by using ejector type microbubble generator in a single reactor
}

\author{
Ji-Young Lim, Hyun-Sik Kim, Soo-Young Park, Jin-Han Kim ${ }^{\dagger}$ \\ Department of Civil and Environmental Engineering, Incheon National University, Incheon 22012, Republic of Korea
}

\begin{abstract}
This study was performed to verify the possibility of nitrification and denitrification in a single reactor. In batch type experiment, optimal point of experimental conditions could be found by performing the experiments. When supply location of microbubbles was located at half of width of the aeration tank and operating pressure of $0.5 \mathrm{bar}$, it was possible for zones in the aeration tank to be separated into anoxic and aerobic by controlling air suction rate according to operating pressure of the generator. To be specific, the concentration of dissolved oxygen (DO) in zone 1 and 2 of the aeration tank could be maintained as less than $0.5 \mathrm{mg} / \mathrm{L}$. Also, in the case of concentration of oxygen in zone 3 and 4 , the concentration of DO was increased up to $1.7 \mathrm{mg} / \mathrm{L}$ due to effects of microbubbles. In continuous flow type experiment based on the results of batch type experiments, the removal efficiency of nitrogen based on T-N was observed as $39.83 \%$ at operating pressure of 0.5 bar and $46.51 \%$ at operating pressure of 1 bar so it was able to know that sufficient air suction rate should be required for nitrification. Also, denitrification process could be achieved in a single reactor by using ejector type microbubble generator and organic matter and suspended solid could be removed. Therefore, it was possible to verify that zones could be separated into anoxic and aerobic and nitrification and denitrification process could be performed in a single reactor.
\end{abstract}

Keywords: Microbubble, Nitrogen removal, Operating pressure, Single reactor, Supply location of microbubbles

\section{Introduction}

In biological treatment processes, nitrification and denitrification processes are required to remove nitrogen gas. For example, A2O and Bardenpho processes separate reactors into an anoxic, anaerobic and aerobic to remove the gas as nitrogen through using nitrification and denitrification. Also, sequencing batch reactor and intermittent aeration are using the change of dissolved oxygen concentration according to time variation [1]. These methods, however, are required of large site area to construct process. In addition, $50 \sim 75 \%$ of consumed energy in a wastewater treatment process is used to supply air to the aeration tank and $40 \sim 60 \%$ of power cost is also used to maintain blower [2, 3]. Therefore, development of processes which are compact and energy-efficient to induce nitrification and denitrification is needed.

Mostly, conventional nitrification and denitrification processes are utilizing a Sharon-Anammox process, which is used to remove $\mathrm{NH}_{3}-\mathrm{N}$ and $\mathrm{NO}_{2}-\mathrm{N}$, and $\mathrm{SymBio}^{\mathrm{TM}}$ using SND (simultaneous nitrification and denitrification) reaction, which is a process that simultaneously induced nitrification and denitrification by keeping the low dissolved oxygen concentration of $0.2 \mathrm{mg} / \mathrm{L}[4,5]$. To induce nitrification and denitrification, many studies demonstrated that HRT (hydraulic retention time), SRT (sludge retention time), concentration of dissolved oxygen, floc size, ratio of $\mathrm{C} / \mathrm{N}$, $\mathrm{pH}$ were crucial factors [6, 7]. Especially, to maintain optimal dissolved oxygen concentration is the most important. Also, many studies about inducing nitrification in low dissolved oxygen concentration have been performed. Bellucci et al. [8] achieved nitrification in low dissolved oxygen concentration of $0.5 \pm 0.3 \mathrm{mg} / \mathrm{L}$ and Pochana and Keller [9] showed optimal concentration of dissolved oxygen, which was about $0.5 \mathrm{mg} / \mathrm{L}$ to induce nitrification and denitrification simultaneously.

These days, many researchers have focused on microbubbles of high level of oxygen transfer efficiency than conventional bubbles [10-12]. The size of microbubbles is smaller than the conventional bubbles so the microbubbles have slow rising velocity, long residence time, and large specific interfacial area. The former research demonstrated that microbubbles with the diameter of
This is an Open Access article distributed under the terms of the Creative Commons Attribution Non-Commercial License (http://creativecommons.org/licenses/by-nc/3.0/) which permits unrestricted non-commercial use, distribution, and reproduction in any medium, provided the original work is properly cited.
Received December 6, 2018 Accepted April 10, 2019

${ }^{\dagger}$ Corresponding author

Email: jinhan@inu.ac.kr

Tel: +82-32-835-8745 Fax: +82-32-835-4344

Copyright (C) 2020 Korean Society of Environmental Engineers 
$10 \mu \mathrm{m}$ have rising velocity of $50 \mu \mathrm{m} / \mathrm{s}$, in another word, $3 \mathrm{~mm}$ per min [13]. To use advantages of microbubbles, many studies were performed to apply the method to the wastewater treatment. Lim [14] demonstrated that it was possible for the aeration tank to be maintained as separated zones, which are an anoxic and aerobic, without partition wall by applying pressurized type of microbubble generator to the aeration tank. However, Lim [14] also mentioned that there was a problem that is "sludge rising" in the aeration tank due to high density and small size of microbubbles. Therefore, Lim [14] showed that the optimal size of bubbles was required to mix MLSS (mixed liquor suspended solids) and maintain concentration of dissolved oxygen. Meanwhile, ejector type microbubble generator has many advantages such as simple design of equipment, a cost-effective method because there is no need of compressor to supply air. Also, size of generated bubbles from it is variable $[15,16]$ so it may be useful to apply air to the aeration tank.

Therefore, to mitigate the disadvantages of the conventional nitrogen removal and the problem of pressurized type microbubble generator as aerator, this study was performed to review the possibility of removing nitrogen in a single reactor by verifying the separation of zones such as an anoxic and aerobic according to supply location of microbubbles and operating pressure of ejector type microbubble generator, when ejector type microbubble generator was applied to the aeration tank.

\section{Experimental Methods}

\subsection{Experimental Apparatus}

This study used the pilot-scale aeration tank, which has effective volume $2.4 \mathrm{~m}^{3}(\mathrm{~W} 3.0 \mathrm{~m} \times \mathrm{H} 1.0 \mathrm{~m} \times \mathrm{D} 0.8 \mathrm{~m})$. Also, there are schematic diagram of ejector type nozzle and process used in the study in Fig. 1. Ejector type microbubble generator consists of pump, nozzle and flow meter. Especially, when water is circulated in generator, air is automatically suctioned into nozzle due to pressure drop. Air suction rate in the nozzle is affected by the water circulation rate according to operating pressure. Also, the size range of generated bubbles from ejector type microbubble generator was from $86 \mu \mathrm{m}$ to $2.98 \mathrm{~mm}$ in this experiment.

\subsection{Experiment and Analysis}

\subsubsection{Batch type experiments}

Batch type experiments were performed to review the separation of anoxic and aerobic zone in a single reactor according to location of microbubble generator and operating pressure. First, to check effects of supply location on the formation of zones, when the ejector type microbubble generator was located at quarters, half and three-quarters of width of the aeration tank as shown in Fig. 1(b), the batch type experiments were performed. Also, in the batch type experiments, the operating pressure of the generator was considered as the operating conditions of the generator at the same time. Here, operating pressure means the pressure by water in the generator, when the water is circulated in the generator to induce suction of air in the nozzle. The concentration of dis
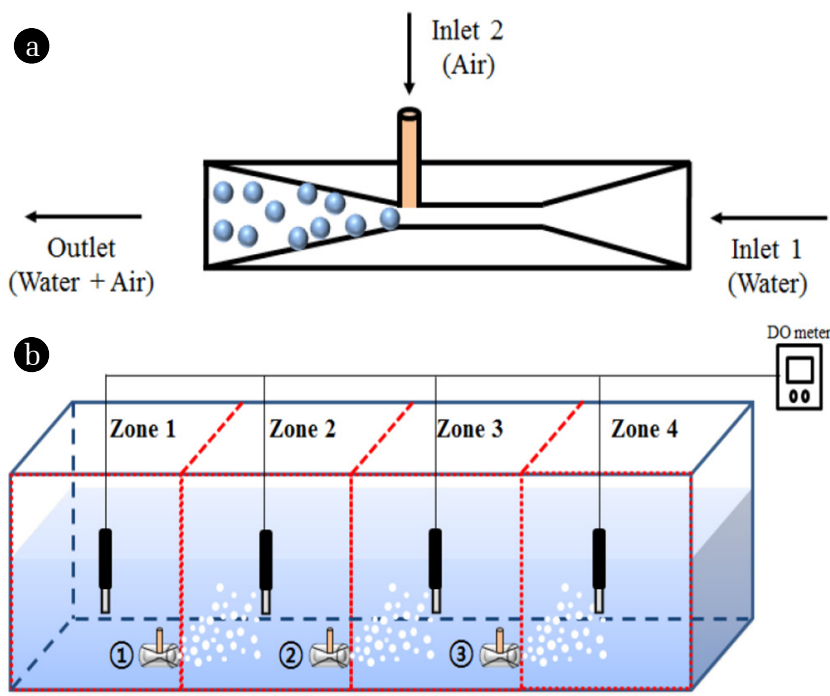

Fig. 1. Schematic diagram of ejector type nozzle (a), and location of the ejector type microbubble generator (b).

solved oxygen was measured at operating pressure of $0.5,0.75$ and 1 bar. Before starting batch type experiments, MLSS, which was 3,000 mg/L concentration, was fully mixed by using conventional air diffuser and concentration of dissolved oxygen was reduced to about $0.5 \mathrm{mg} / \mathrm{L}$. Finally, to compare the performance of the conventional air diffuser and the ejector type microbubble generator, the conventional air diffuser was used for experiments and the quantity of supplied air to the conventional air diffuser was the same as the quantity of air suction rate of the ejector type microbubble generator. DO sensor was located at $0.5 \mathrm{~m}$ below of surface water and temperature of water was $17 \pm 0.5^{\circ} \mathrm{C}$.

\subsubsection{Continuous flow type experiments}

Continuous flow type experiments were performed to check the removal of nitrogen and organic matter based on the batch type results. Continuous flow type experiments were operated in conditions that concentration of MLSS was 3,000 mg/L, HRT was $8 \mathrm{~h}$, rate of internal recirculation and return sludge were, respectively 1Q and 0.8Q of influent based on $8 \mathrm{~h}$ of HRT, temperature of water was $17 \pm 0.5^{\circ} \mathrm{C}$. Supply location of microbubbles was located at half of width of the aeration tank based on results of batch type experiments and concentration of dissolved oxygen,

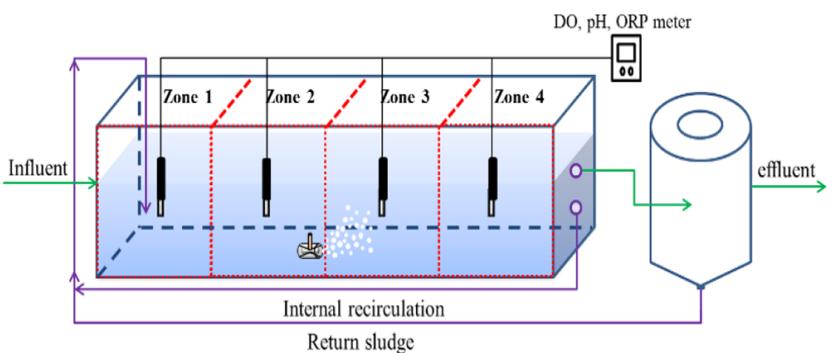

Fig. 2. The location of $\mathrm{DO}, \mathrm{pH}, \mathrm{ORP}$ sensors and the ejector type microbubble generator. 
Table 1. Measurement and Analysis Items

\begin{tabular}{|c|c|c|c|c|c|}
\hline \multirow{2}{*}{ Items } & \multirow{2}{*}{ Site } & \multicolumn{4}{|c|}{ Location } \\
\hline & & Zone 1 & Zone 2 & Zone 3 & Zone 4 \\
\hline Measurement items $^{1)}$ & Aeration tank & $\mathrm{DO}, \mathrm{pH}, \mathrm{ORP}$ & $\mathrm{DO}, \mathrm{pH}$ & $\mathrm{DO}, \mathrm{pH}$ & DO, $\mathrm{pH}, \mathrm{ORP}$ \\
\hline \multirow{2}{*}{ Analysis items ${ }^{2)}$} & Influent & \multicolumn{4}{|c|}{ SS, BOD, $\mathrm{COD}_{\mathrm{Cr}}, \mathrm{NH}_{4}^{+}-\mathrm{N}, \mathrm{NO}_{3}-\mathrm{N}, \mathrm{T}-\mathrm{N}$} \\
\hline & Effluent & \multicolumn{4}{|c|}{$\mathrm{SS}, \mathrm{BOD}, \mathrm{COD}_{\mathrm{Cr}}, \mathrm{NH}_{4}{ }^{+}-\mathrm{N}, \mathrm{NO}_{3}-\mathrm{N}, \mathrm{T}-\mathrm{N}$} \\
\hline
\end{tabular}

1) DO meter: Pro ODO ${ }^{\circledR}$, YSI, USA (measurement range 0 50 mg/L) / ORP meter: WSO-100, DIK, Korea (measurement range -1,500 15.00 $\mathrm{mV}$ ) / pH meter: 4,010-1 MultiLab IDS, YSI, USA (measurement range $-0.000 \sim 14.000$ )

2) SS, BOD: 2017 Water pollution standard method, Ministry of Environment in South Korea / $\mathrm{COD}_{\mathrm{Cr}}, \mathrm{NH}_{4}{ }^{+}-\mathrm{N}, \mathrm{NO}_{3}-\mathrm{N}, \mathrm{T}_{-\mathrm{N}}$ : Hach vial with DR2700

$\mathrm{pH}$, ORP were measured at operating pressure of 0.5 and 1 bar. Also, DO, pH, ORP sensors were located at the same position in the batch type experiments as shown in Fig. 2. In addition, to analyze removal of organic matter, characteristics of nitrification and denitrification, measurement and sampling were carried in influent, effluent, the aeration tank. SS and BOD were analyzed by the method of water pollution standard method in South Korea. Also, $\mathrm{COD}_{\mathrm{Cr}}, \mathrm{NH}_{4}{ }^{+}-\mathrm{N}, \mathrm{NO}_{3}-\mathrm{N}$, T-N were analyzed by using Hach vial with DR2700.
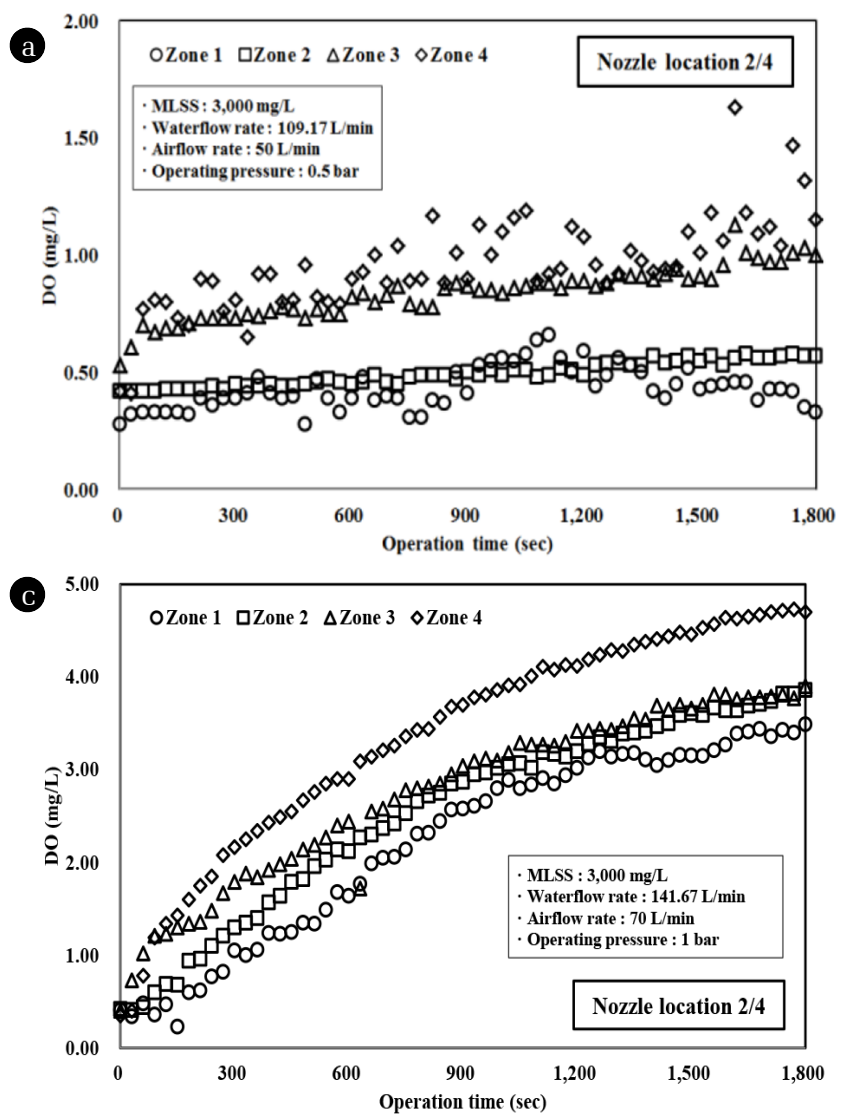

Fig. 3. Concentration of dissolved oxygen by using ejector type microbubble generator (a), (b), (c) and conventional air diffuser (d).

\section{Results and Discussion}

\subsection{Batch Type Experiments}

The results of measurement of concentration of dissolved oxygen and supply location of bubbles were shown in Fig. 3(a). As shown in Fig. 3(a), when supply location of microbubbles was located at half of the aeration tank and operating pressure was 0.5 bar, concentration of dissolved oxygen was measured from 0.3 to $1.7 \mathrm{mg} / \mathrm{L}$. Also, in zone 1 and 2, concentration of dissolved
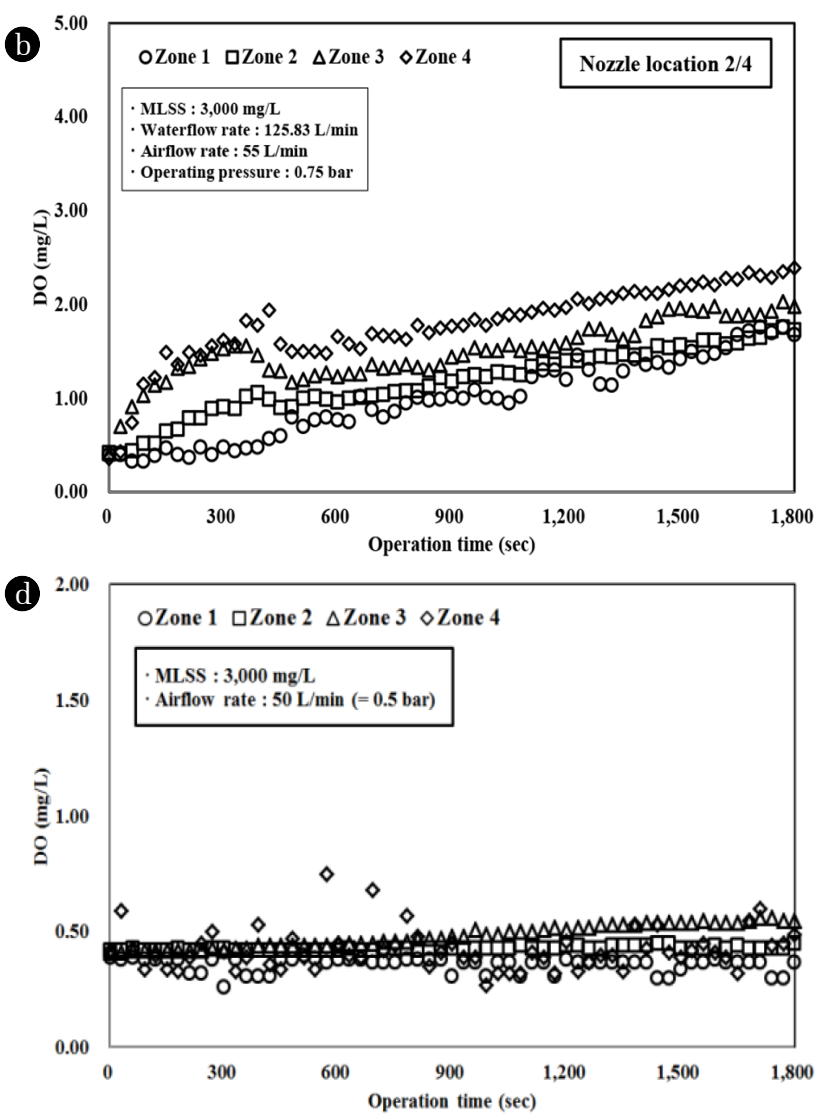
oxygen was measured less than $0.5 \mathrm{mg} / \mathrm{L}$. In addition, in zone 3 and 4, concentration of dissolved oxygen was gradually increased and measured more than $1.0 \mathrm{mg} / \mathrm{L}$ after a half hour of starting the experiment so an anoxic and anaerobic conditions based on the concentration of dissolved oxygen could be achieved. When supply location of microbubbles was sited at quarter, there was limitation of separating zones. Also, at three-quarters of supply location of microbubbles, concentration of dissolved oxygen was about $1.5 \mathrm{mg} / \mathrm{L}$ in zone 4 . Besides, concentration of dissolved oxygen was increased up to about $0.91 \mathrm{mg} / \mathrm{L}$ in zone 1, as time went by, was decreased. Meanwhile, when ejector type microbubble generator was operated at 0.75 and 1.0 bar of operating pressure, concentration of dissolved oxygen was consistently increased in all zones due to the increase of air suction rate so it was impossible to verify that zones were separated at 0.75 and 1.0 bar of operating pressure in the batch type experiment. In the performance comparison tests, as shown in Fig. 3(b), concentration of dissolved oxygen was measured less than $0.5 \mathrm{mg} / \mathrm{L}$ in all sections, when the conventional air diffuser was used to supply air to the aeration tank and it seemed to be caused by the difference of bubble dissolution rate between the conventional bubbles and microbubbles [12]. Therefore, in the batch type experiments, the experimental conditions to verify separation of zones could be found, when the location of microbubble generator was located at the half of width of the aeration tank and at the operating pressure of 0.5 bar.

\subsection{Continuous Flow Type Experiments}

\subsubsection{Concentration of dissolved oxygen, $\mathrm{pH}$ and ORP}

Based on the results of the batch type experiments, supply location of microbubbles was sited at the half of width of the aeration tank and concentration of dissolved oxygen was measured at operating pressure of 0.5 bar. However, to induce sufficient nitrification, the experiment at operating pressure of 1 bar was added. Also, results of test were shown in Fig. 4. At 0.5 and 1.0 bar of operating pressure, each of the average of air suction rate was 50 and 70 $\mathrm{L} / \mathrm{min}$. Concentration of dissolved oxygen in zone 3 , which is directly affected by microbubbles generated at half of width of the aeration tank, was the highest from 0.88 to $2.40 \mathrm{mg} / \mathrm{L}$. Also, when ejector type of microbubble generator was operated at $1 \mathrm{bar}$, concentration of dissolved oxygen was the highest as $2.40 \mathrm{mg} / \mathrm{L}$ so the results of concentration distribution were the same results as shown in the former study [14]. In addition, each of concentration of dissolved oxygen in zone 1,2 and 4 was $0.28 \sim 0.37,0.44 \sim 0.57$ and $0.28 \sim 0.52 \mathrm{mg} / \mathrm{L}$ so it was able to verify that the increase of operating pressure, which means the increase of air suction rate, did not sufficiently have effect on concentration of dissolved oxygen in zone 1, 2 and 4 than zone 3. During the experiments, $\mathrm{pH}$ of influent was from 7.27 to 7.86 . Also, at $1.0 \mathrm{bar}$ of operating pressure, each of $\mathrm{pH}$ of zone 1, 2, 3 and 4 was 6.00 7.56, 6.50 7.58, 6.53 7.58 and 6.28 7.60. In zone 3, pH was decreased; it seemed to be influenced by nitrification of fully mixing of MLSS and concentration of dissolved oxygen. In zone 1, although result of measuring ORP indicated -19 -434 $\mathrm{mV}$, which is conditions of an anaerobic $(-150 \sim-350 \mathrm{mV})$ and anoxic $(50 \sim-150 \mathrm{mV}), \mathrm{pH}$ was also decreased because it was hard to fully mix MLSS and concentration of
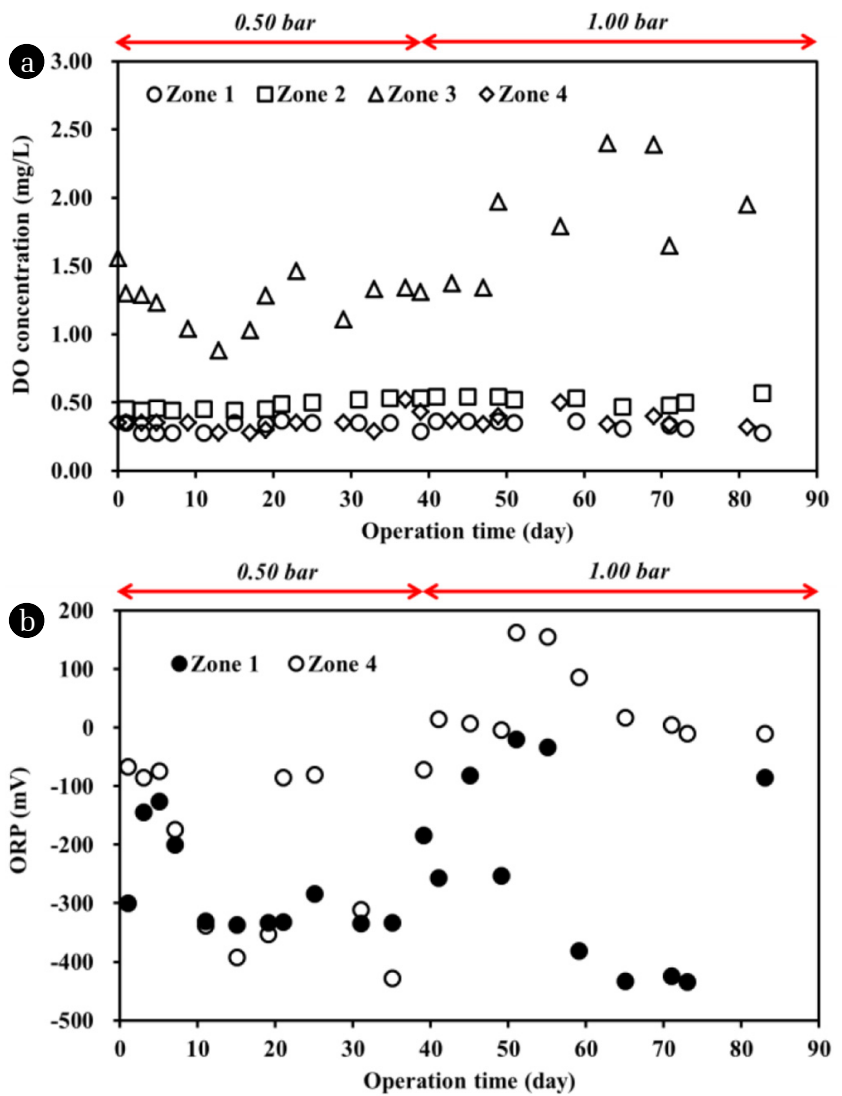

Fig. 4. Concentration of dissolved oxygen (a), and ORP (b) according to operation pressure of microbubble generator.

dissolved oxygen. Therefore, agitator was installed to fully mix MLSS at the slowest speed to not affect concentration of dissolved oxygen in zone 1.

\subsubsection{Removal of organic matter and suspended solid}

Fig. 5 shows removal characteristics of BOD, $\mathrm{COD}_{\mathrm{Cr}}$, SS (suspended solid) in a single reactor. The range of $\mathrm{BOD}$ and $\mathrm{COD}_{\mathrm{Cr}}$ were 151 399 and 259 627 mg/L in influent, each of the average of each BOD at 0.5 and 1 bar of operating pressure was 42.80 and $54.96 \mathrm{mg} / \mathrm{L}$ in effluent. Also, each of removal efficiency of BOD at the same conditions was 78.53 and $76.55 \%$. Meanwhile, each of the average of $\mathrm{COD}_{\mathrm{Cr}}$ at 0.5 and 1 bar of operating pressure was 70.75 and $62.62 \mathrm{mg} / \mathrm{L}$ in effluent. In addition, each of removal efficiency of $\mathrm{COD}_{\mathrm{Cr}}$ at the above mentioned conditions was 81.15 and $82.14 \%$. Commonly, in a conventional activated sludge process, concentration of dissolved oxygen in the aeration tank was maintained to from 2.0 to $4.0 \mathrm{mg} / \mathrm{L}$ [17]. In this test, however, it was possible that $\mathrm{BOD}$ and $\mathrm{COD}_{\mathrm{Cr}}$ were stably removed while concentration of dissolved oxygen in the aeration tank was maintained in various conditions that concentration of dissolved oxygen was from 0.28 to $2.40 \mathrm{mg} / \mathrm{L}$. Therefore, the quantity of supplied air to the aeration tank might have rarely effect on removal of organic matter, which was mentioned in Kim's study [18]. Fig. 5 (c) shows that the average of SS is from 93 to $300 \mathrm{mg} / \mathrm{L}$ in 

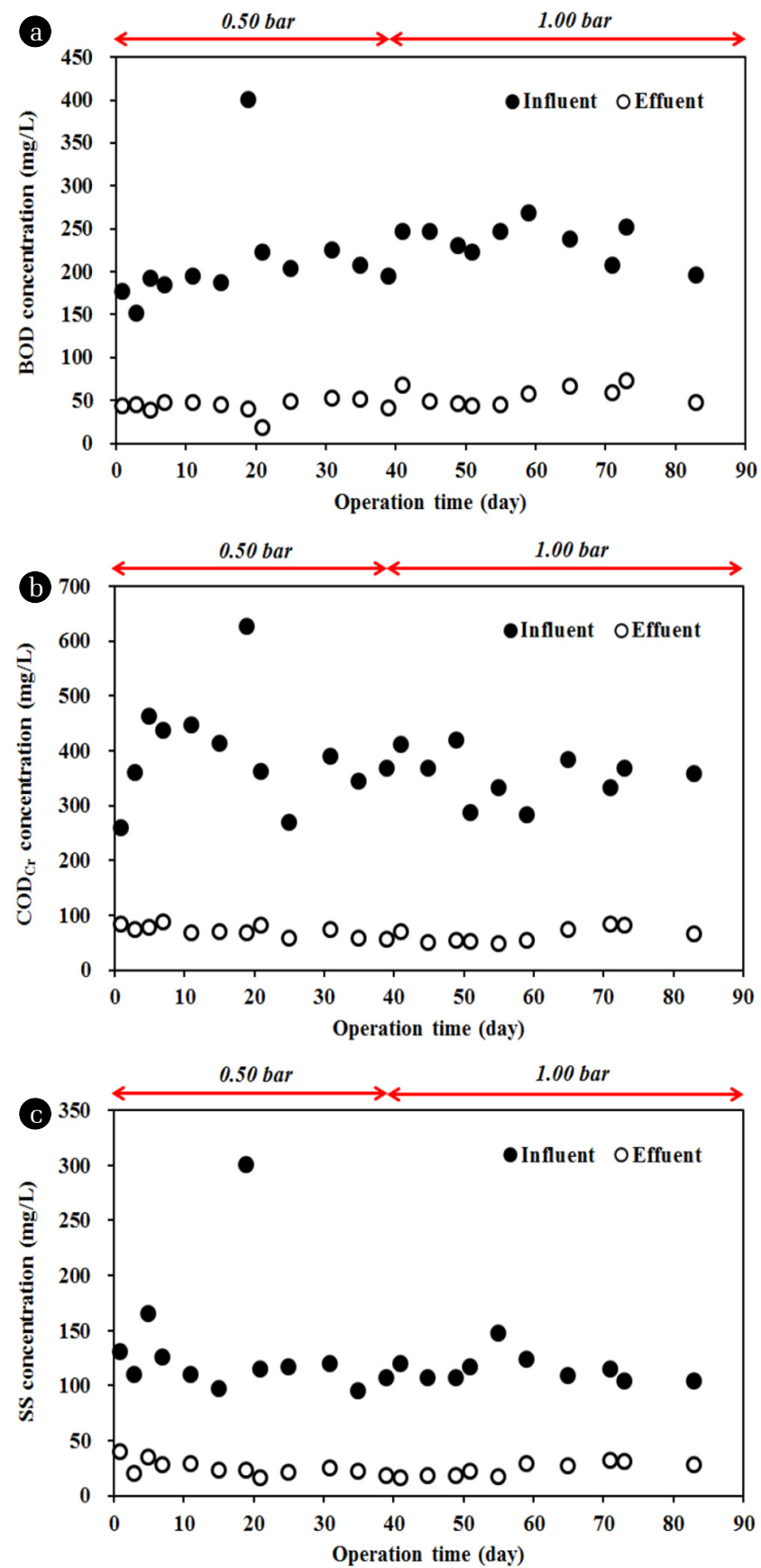

Fig. 5. Concentration of $\mathrm{BOD}(\mathrm{a}), \mathrm{COD}_{\mathrm{Cr}}(\mathrm{b})$, and SS (c) according to operating pressure

influent and each of the average of effluent was 25 and 23.75 $\mathrm{mg} / \mathrm{L}$ according to operating conditions. Also, each of removal efficiency of SS was calculated to 79.74 and $78.94 \%$ in the same conditions. It seemed to be adversely influenced by the variable size of bubbles generated from ejector type microbubble generator [19], especially micro-size bubbles which have low speed of rising, long residence time than conventional bubbles and the effect of attachment to floc [15].

\subsubsection{Removal of nitrogen}

Fig. 6 shows removal characteristic of $\mathrm{NH}_{3}-\mathrm{N}, \mathrm{NO}_{3}-\mathrm{N}$, T-N in influent and effluent. In influent, concentration of $\mathrm{NH}_{3}-\mathrm{N}$ was stably shown from 25 to $36 \mathrm{mg} / \mathrm{L}$. In effluent, however, each of concentration of $\mathrm{NH}_{3}-\mathrm{N}$ was 22.49 and $5.43 \mathrm{mg} / \mathrm{L}$ according to operating pressure and each of the average of removal efficiency of $\mathrm{NH}_{3}-\mathrm{N}$ was 28.24 and $80.49 \%$ at the above mentioned conditions. In chapter of 3.2.1, the quantity of air supplied to the aeration tank did not have
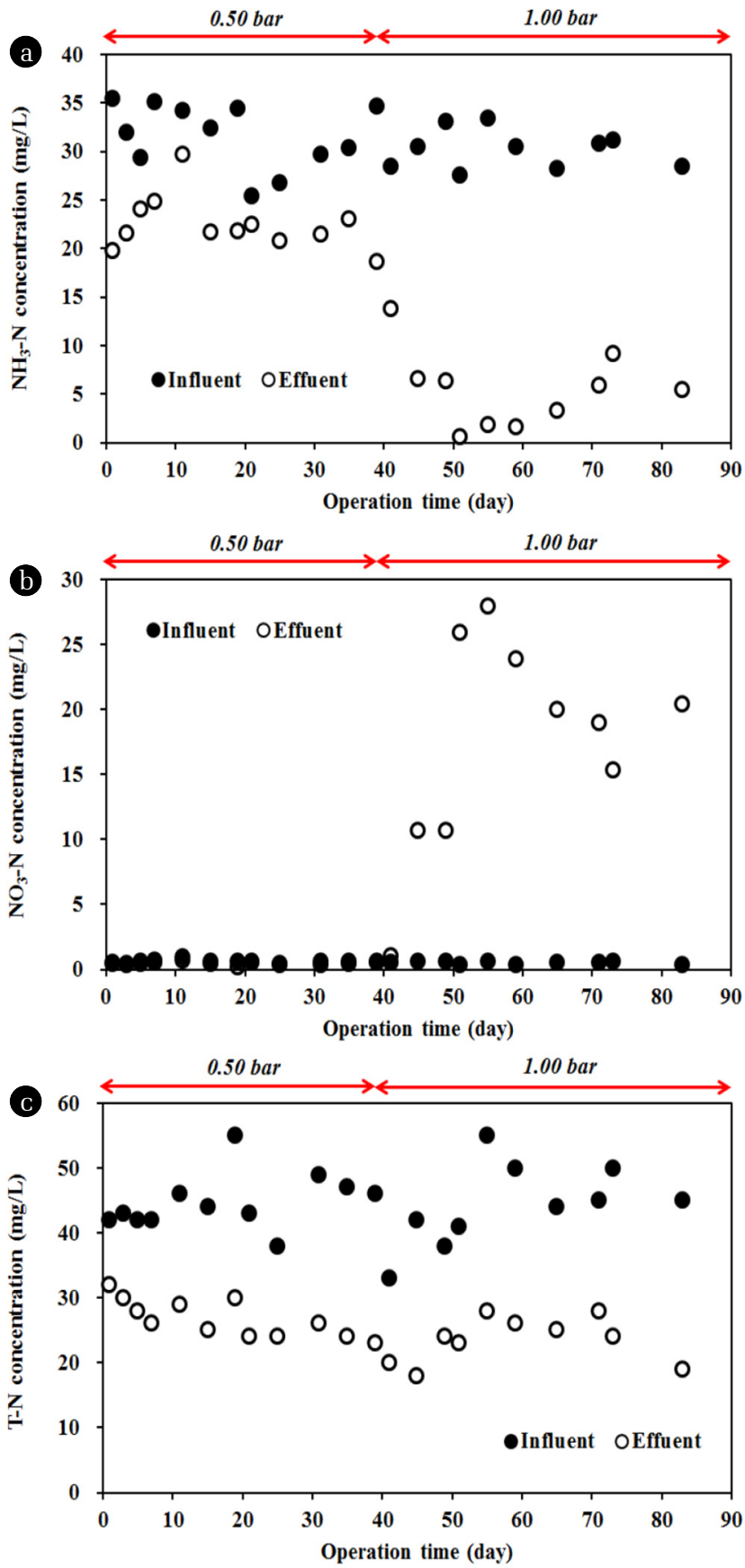

Fig. 6. Concentration of $\mathrm{NH}_{3}-\mathrm{N}$ (a), $\mathrm{NO}_{3}-\mathrm{N}$ (b), and $\mathrm{T}-\mathrm{N}$ (c) according to operation pressure of microbubble generator. 
effect on removal of organic matter, but had significantly impact on removal of $\mathrm{NH}_{3}-\mathrm{N}$ due to need of oxygen for nitrification. This is because increased quantity of air supplied to the aeration tank by augmenting operating pressure facilitates nitrification. Therefore, it shows that operating condition should be maintained to 1 bar, which is possible to keep concentration of dissolved oxygen from 1.4 to $2.4 \mathrm{mg} / \mathrm{L}$ by controlling air suction rate, for nitrification. Especially, Zhang et al. [20] demonstrated that each of removal efficiency of $\mathrm{NH}_{3}-\mathrm{N}$ and $\mathrm{T}-\mathrm{N}$ was 55.4 and $55.1 \%$ in experiments that maintained $8 \mathrm{~h}$ of HRT by using synthetic wastewater. Meanwhile, in analysis of $\mathrm{NO}_{3}-\mathrm{N}$, concentration of $\mathrm{NO}_{3}-\mathrm{N}$ in influent was from 0.3 to $0.9 \mathrm{mg} / \mathrm{L}$ and each of the average of level of $\mathrm{NO}_{3}-\mathrm{N}$ in effluent was $0.41 \mathrm{mg} / \mathrm{L}$ at $0.5 \mathrm{bar}$ of operating pressure and $17.48 \mathrm{mg} / \mathrm{L}$ at 1 bar of operation pressure. Difference of $\mathrm{NO}_{3}-\mathrm{N}$ between 0.5 and 1.0 bar of operating pressure was caused by air suction rate as the same reason mentioned in the case of $\mathrm{NH}_{3}-\mathrm{N}$. In analysis of T-N, concentration of T-N in influent was from 33 to $55 \mathrm{mg} / \mathrm{L}$ and each of the average of removal efficiency of T-N was $39.83 \%$ at 0.5 bar of operating pressure and $46.51 \%$ at 1.0 bar of operating pressure. Although removal efficiency of T-N at 1.0 bar of operating pressure was improved by $15 \%$ compared to the removal efficiency at 0.5 bar of operating pressure, removal efficiency of T-N seemed to be impeded by limitation of denitrification in zone 1 and 2, which was caused by internal recirculation from zone 4 which was an aerobic zone that had existing microbubbles, in spite of low level of dissolved oxygen.

\section{Conclusions}

In the experimental results, the following conclusions are obtained when ejector type microbubble generator is applied to the aeration tank to remove nitrogen in a single reactor.

In the batch type experiment, when supply location of microbubbles is located at half of width of the aeration tank, it is possible to separate zones into anoxic and aerobic at 0.5 bar of operating pressure for the generator. Especially, in zone 1 and 2, concentration of dissolved oxygen was less than $0.5 \mathrm{mg} / \mathrm{L}$ in the test. And, in zone 3 and 4, level of dissolved oxygen was increased up to 1.7 $\mathrm{mg} / \mathrm{L}$ in the test. Also, in the continuous type experiment, when ejector type microbubble generator is operated at 0.5 and $1.0 \mathrm{bar}$ of operating pressure, segregation of zones is ideally formed.

$\mathrm{BOD}, \mathrm{COD}_{\mathrm{Cr}}$ and SS is stably removed in the continuous type experiment. And, each of the average of removal efficiency of $\mathrm{BOD}, \mathrm{COD}_{\mathrm{Gr}}$ and SS is shown to about $80 \%$. In addition, Air supplied to the aeration tank according to change of operating pressure does not have impact on removal of organic matter.

By analyzing $\mathrm{NH}_{3}-\mathrm{N}, \mathrm{NO}_{3}-\mathrm{N}$ and T-N, it is able to verify optimal operating pressure of ejector type microbubble generator in this experiment. When ejector type microbubble generator is operated at $1.0 \mathrm{bar}$ of operating pressure, although denitrification process seems to be impeded due to existing microbubbles in internal recirculation, nitrification process is facilitated by increased air suction rate due to the increase of operating pressure. Also, removal efficiency of T-N is about $46 \%$, which is improved by $15 \%$ compared to the removal efficiency at 0.5 bar of operating pressure.
Therefore, through changing supply location of microbubbles and operating pressure, it is possible to verify that zones can be separated into anoxic and aerobic. Also, nitrification and denitrification process can be performed in a single reactor.

\section{Acknowledgement}

This work (Grants No. C0530519) was supported by Business for Cooperative R\&D between Industry, Academy, and Research Institute funded Korea Ministry of SMEs and Startups in 2017.

\section{References}

1. Choi MS, Lee TJ. Nitrogen removals according to aeration/non-aeration periods in the intermittent aeration reactor and analysis of microbial community. Environ. Eng. Res. 2014;36:42-48.

2. Åmand L, Olsson G, Carlsson B. Aeration control-a review. Water Sci. Technol. 2013;67:2374-2398.

3. Lee HK. A Study on the characteristics of organics and nitrogen removal using Intermittent Aeration fluidized bed by Swirl Flow. J. Korean Soc. Environ. Technol. 2013;14:145-152.

4. Khanitchaidecha W, Nakaruk A, Koshy P, Futaba L. Comparison of simultaneous nitrification and denitrification for three different reactors. BioMed Res. Int. 2015;2015:1-7.

5. Lee SH, Park NB, Park SM, Jun HB. Effect on nitrogen removal in the intermittent aeration system with the anaerobic archaea added. J. Korean Soc. Environ. Eng. 2005;27:1186-1192.

6. Stenstrom MK, Song SS. Effects of oxygen transport limitation on nitrification in the activated sludge process. Res. J. Water Pollut. Control Fed. 1991;63:208-219.

7. Ju LK, Huang L, Trivedi H. Simultaneous nitrification and denitrification through low-do operation. In: Proceedings of the Water Environment Federation. WEFTEC; 2006; Dallas. p. 1583-1597.

8. Bellucci M, Ofiţ,eru ID, Graham DW, Head IM, Curtis TP. Low-dissolved-oxygen nitrifying systems exploit ammonia-oxidizing bacteria with unusually high yields. Appl. Environ. Microbiol. 2011;77:7787-7796.

9. Pochana K, Keller J. Study of factors affecting simultaneous nitrification and denitrification (SND). Water Sci. Technol. 1999;39:61-68.

10. Terasaka K, Hirabayashi A, Nishino T, Fujioka S, Kobayashi D. Development of microbubble aerator for waste water treatment using aerobic activated sludge. Chem. Eng. Sci. 2011;66:3172-3179.

11. Hanotu JO, Bandulasena H, Zimmerman WB. Aerator design for microbubble generation. Chem. Eng. Res. Des. 2017;123: 367-376.

12. Tekile A, Kim Ih, Lee JY. Extent and persistence of dissolved oxygen enhancement using nanobubble. Environ. Eng. Res. 2016;21:427-435.

13. Li P. Development of advanced water treatment technology [dissertation]. Tokyo: Keio Univ.; 2006.

14. Lim JY, Kim HS, Park DS, et al. Characteristic of mixing 
and DO concentration distribution in aeration tank by microbubble supply. J. Korea Academia-Industrial cooperation Soc. 2016;17:251-259.

15. Parmar R, Majumder SK. Microbubble generation and microbubble-aided transport process intensification-A state-of-the-art report. Chem. Eng. Process.: Process Intensification 2013;64: 79-97.

16. Kim HS, Lim JY, Park SY, Kim JH. Effects of distance of breaker disk on performance of ejector type microbubble generator. J. Civil Eng. 2018;22:1096-1100.

17. Park NB, Choi WY, Yoon AH, Jun HB. Effects of DO concentration on simultaneous nitrification and denitrification
(SND) in a Membrane Bioreactor (MBR). Korean J. Environ. Agric. 2009;28:371-377.

18. Kim IK, Lee SM, Lim KH. Effect of air-flow on enhanced nutrient removal and simultaneous nitrification/denitrification in DMR biofilm process. J. Korean Soc. Environ. Eng. 2008;30:992-998.

19. Maeda Y, Hosokawa S, Baba Y, Tomiyama A, Ito Y. Generation mechanism of micro-bubbles in a pressurized dissolution method. Exp. Therm. Fluid Sci. 2015;60:201-207.

20. Zhang P, Zhou Q. Simultaneous nitrification and denitrification in activated sludge system under low oxygen concentration. Front Environ. Sci. Eng. China 2007;1: 49-52. 